\title{
CUSTOMER SATISFACTION AS A KEY FACTOR IN BUILDING AND MAINTAINING COMPETITIVE ADVANTAGES OF COMPANIES
}

\author{
Zijada Rahimić \\ School of Economics and Business Sarajevo, Bosnia and Herzegovina \\ E-mail: zijada.rahimic@efsa.unsa.ba \\ Kenan Uštović \\ NCH Bosnia LTD Sarajevo, Bosnia and Herzegovina \\ E-mail: kenan.ustovic@nch.com
}

\begin{abstract}
For building and preservation of long-term competitive advantages, it is not enough that companies are just better and faster than their competitors. Competitor orientation strategy, without aim for customers' satisfaction may lead company to "Cul-de-sac". This situation is an indicator that management decisions depend exclusively on the moves of competitors. In doing so, companies forget the real reason for their existence, customers satisfaction. Knowledge about customer needs and desires, identified in process of building sales network focused on the customer, can help top management of the company to apply it through value creation building. The main goal of this research is to explore companies' awareness level about the customer satisfaction as a key element in process of building competitive advantages based on sales policy differentiation. Research was conducted through individual interview survey based of pre-prepared questionnaire and includes companies engaged in B2B sales, not sales to end customers. Research results should demonstrate a difference in perception of customer satisfaction in international companies in Bosnia and Herzegovina, on the one, and domestic companies, on the other hand. Analyzing the results of research we make a conclusion about possibilities that companies build a CustomerOrientation Sales (COS) Model.
\end{abstract}

Key words: sales network, sales team, Customer-Oriented Sales (COS) Model, customer satisfaction, competitiveness, differentiation, B2B sales.

\section{Introduction}

Themostimportantgoalforallcompaniesistoachievebusinessefficiencyandeffectiveness, in order to meet customer needs. In the processes of globalization and internationalization the emphasis is on satisfying customer needs, as a prerequisite for sustainable growth and development. Companies that do not understand and meet the expectations and demands of customers are in danger of losing purpose of their existence, and become irrelevant, or the purpose for themselves. For customer satisfaction measurement the most important standard is the 9001:2000 ISO Standard. ISO 9001:2000 specifies requirements for a quality management system where an organization needs to demonstrate its ability to consistently provide product that meets customer and applicable regulatory requirements, and aims to enhance customer satisfaction through the system and the assurance of conformity to customer and applicable regulatory requirements (Arnett and Badrinarayanan, 2005; Gotzamani, 2010). 
PROBLEMS

OF MANAGEMENT

IN THE $21^{\text {st }}$ CENTURY

Volume 3, 2012

92

Today, the creation of a sales policy that is primarily based on the aspirations and needs of the customer rather than on sales and the achievement of short-terms benefits, is increasingly becoming the key activity of a long-term and market oriented companies. They realized they cannot reach long-term business ambitions only by sales and that they, most of all, have to help their customers so that they could help them. The customer's needs are constantly changing, and companies need to adapt but keeping in mind that customers always want two things: increase their performances (production, sales, profit, content) and/or decrease others (costs, fallout, expenses, discontent, worries). The very important principle of quality management is customer orientation stating that a supplier hat to ensure most adequate indicators of (Brdarević, 2002):

1. Understating of the current and future customer needs for specific product and services,

2. Manners of meeting customer demands (adaptation of one's own processes to create the desired quality of products and services), and

3. Development goals to satisfy customer expectations.

Every company should know that their buyers are more value-conscious and informed than ever before. Not being aware of the new possibilities, companies are convinced that they will gain significant market share by developing new products. However, by doing so they ignore statistics that say that $80 \%$ of all new products fail successful national market placement (Kovačić, 2011). Most of them fail because they are based on pale ideas. Others may have good ideas that are unique and attractive, but are useless nonetheless in the context of their business. For the sake of achieving better short-term results, companies often make the mistake of offering something new, without taking into consideration the buyers' previous experiences with other new products. For establishing good relationship with corporate customers, company need to have CRM strategy developed. Customer-needs-driven CRM strategy is focused on improving customer relationship and this approach involves two steps (Dowling, 2002):

1. information technology is used to uncover insights regarding customer needs, and

2. special programs are developed to meet the discovered needs (e.g., the development of customer-specific processes and procedures)

If company wants to be able to use CRM strategy as differentiation tool during the competitive advantage building, it must be sure that customer is aware of the value that will be obtained by purchasing products or services, probably at higher price. The following text presents a unique research on the territory of Bosnia and Herzegovina about how much companies in this country pay attention to the customer relationship development issue, taking into account the differences in the perception of the CRM strategy for international and domestic companies.

\section{CRM as a Part of cos Model}

The secret of success in business with customers is based on a value proposition that needs to be delivered to the customer, taking in account all the necessary information, knowledge, existing know-how, and sales models that put the customer at the center of attention. Customer-Oriented Sales (COS) Model represents a unique integration of available information 
and modern sales model that company can use like vantage in creating detail plan for rapid economic development. This system does not infer that company must fully replace the existing sales models, but it is an integral part of the process of transforming the entire company, aimed at better satisfying customer needs. The market is now much more complex and dynamic then before.

If one company is priced much more superior that its competitors, it is important to note that in the near future it probably will not be. Price is an element that has its margins of increase and decrease, whose breakthrough implies that company will not be able to find market segment, or in case of low prices would directly threat the innovation, creativity, and therefore the whole future of its business. A company only alternative is to create something scarce, something valuable and something that people will pay more for (Godin, 2010).

Today companies need to invest much more knowledge and research, if they want to attract and retain customers. The hardest part of sales process for sales team is that they have to become some kind of diagnostician. They need to develop a clear and specific definition of all needs their customers might have, have the knowledge about expected value for customers and prepare demonstrations to the customer's decision makers who need to recognize all benefits that will be obtained using the presented products and services. Diagnosis involves mutual and continual understanding of the causes of problem before considering the final proposal. If the diagnosis is not done in a proper manner it will provide an opportunity for the customer to perceive "selling" rather than "solving problems", even if company has a good offer. Potential customer will form an opinion that the sales representative does not understand his problems and propose solution of the problem before taking a diagnosis. It is important that customer understands the offer and accepts the diagnosis of the problem before presenting options for resolution. This approach is not always represented in companies' sales portfolio, and the main reason for that we can primarily seek in vendor's sales management. Those companies are trapped in an outdated approach to value creation that has emerged over the past few decades. They continue to view value creation narrowly, optimizing short-term financial performance in a bubble while missing the most important customer needs and ignoring the broader influences that determine their longer-term success (Porter and Kramer, 2011).

COS Model is trying to encourage changes in the companies to recognize all customers' needs. This model "doesn't allow" companies to be primarily concerned about their own successes and needs. In fact, companies should measure their success based on how much they helped their customers to achieve what they really want. Companies need to realize that they should not focus only on short-term benefits, but they have to understand the opportunities how to create added value for their customers in all important parts of their business. Customers are increasingly aware of the value they can get for their money, and they want a high quality product or service which will be used in end customers selling process. Companies need to prepare and arrange their business not only for direct B2B customers, but also to end customers. Today it is not enough to satisfy only your first customer in supply chain. Managers and sales representatives need to know what motivate the end customer too. In order to properly satisfy all customer requirements, companies need to know who are the customers' customers, what they truly need, what their attitudes and problems are, and which decision-making model they are using. If the company wants to make an order, they must observe the entire sales process backwards, from end customer needs to needs of their first direct customer. Research conducted in the German-speaking area, using sample of 110 companies in branches: engineering, service sector and the chemical industry, had a goal to determine whether and how companies contact with customers' customers. Managers have a variety of methods at their disposal. The Table 1 shows which instruments are commonly used for establishing contact with end customers, whereby it was possible to indicate all of them. 
PROBLEMS

OF MANAGEMENT

IN THE $21^{\text {st }}$ CENTURY

Volume 3, 2012

Table 1. Instruments for contact with customer's customers.

\begin{tabular}{|c|c|}
\hline Instrument & \% of companies \\
\hline Sales Activities & 63 \\
\hline Advertising/Promotion & 60 \\
\hline Customer Service & 49 \\
\hline Price Creation & 26 \\
\hline Ingredient Branding & 9 \\
\hline Other & 17 \\
\hline
\end{tabular}

Source: Kleinaltenkamp, M., et al., (2011), p. 44.

One of the most popular instruments for the marketing strategy implementation is Ingredient Branding, through managers create a brand for something that is an integral part of another product. Example of this is Intel processor for personal computers. In B2B sector this instrument does not play a major role. Managers use, more often Sales Activities or Customer Service in their value chain.

The companies recognizing the importance of the new approach have also to understand that their sales representatives cannot any longer be isolated as unique individuals. They need to become leaders of sales teams that will direct and organize expert groups from different departments within the firm (finance, marketing, legal service, manufacturing...). Although many of them might doubt their abilities in the beginning, the COS approach will help them recognize their interpersonal skills. The company should always strive to implement the Total Quality Management System (Plank and Blackshear, 1997; Oakland, 1998), which implies the concept that reduces or even eliminates the barriers between business functions in the company. Here we can recognize the characteristic horizontal coordination among business functions (Šehić, 2002). The main objective of linking all functions in the company is cooperation and interaction that will result in company's better use of ways to identify and satisfy customer needs.

Customer relationship management $(\mathrm{CRM})$ is a widely-implemented strategy for managing a company's interactions with customers, clients and sales prospects. It involves using technology to organize, automate, and synchronize business processes principally sales activities, but also those for marketing, customer service, and technical support. The overall goals are to find, attract, and win new clients, nurture and retain those the company already has, entice former clients back into the fold, and reduce the costs of marketing and client service. Customer relationship management describes a company-wide business strategy including customerinterface departments as well as other departments (Bonsai, 2001; Richard, Thirkell and Huff, 2007; Rogers, Stone and Foss, 2008; Labus and Stone, 2010). 


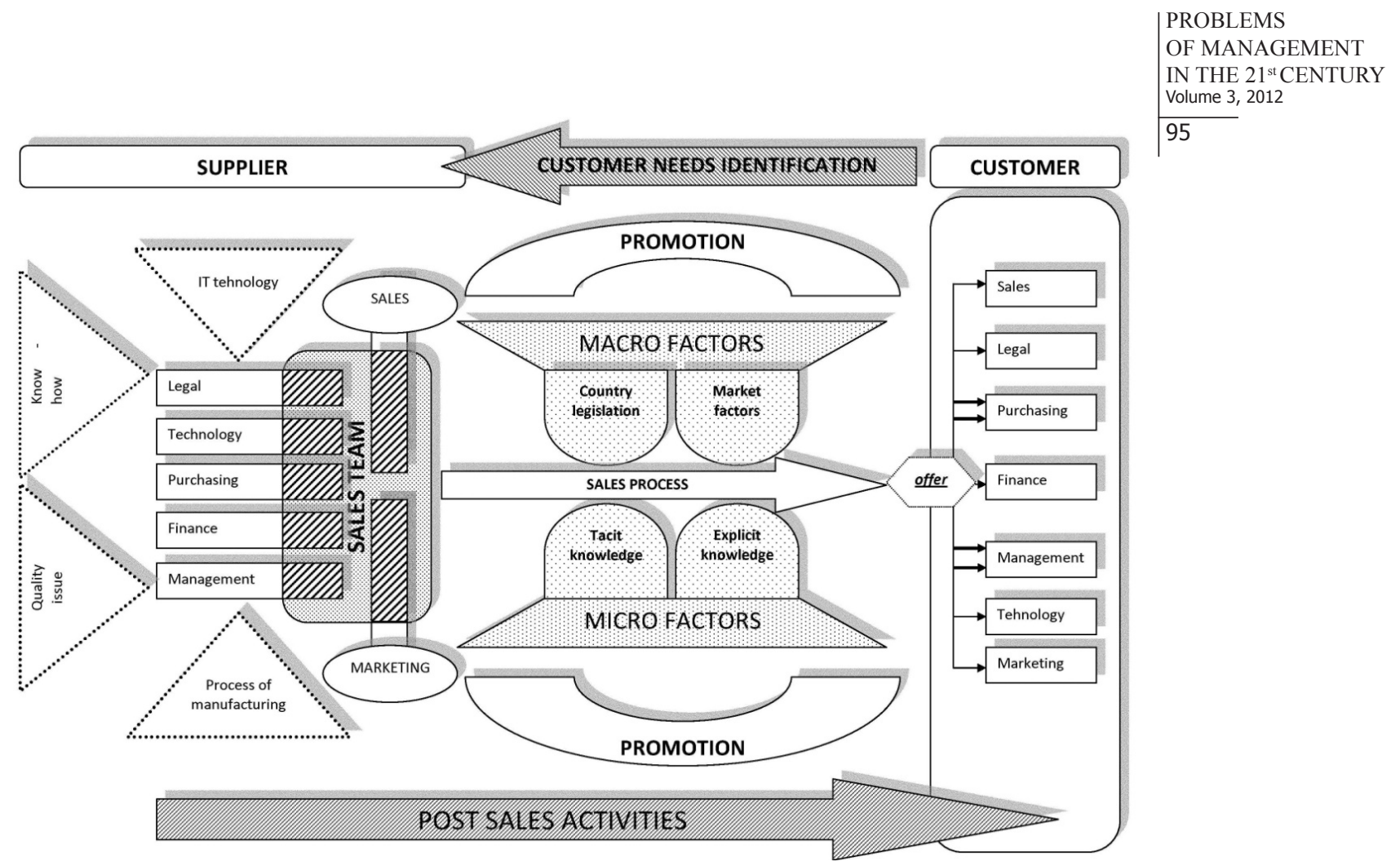

Figure 1: Customer-Oriented Sales (COS) Model.

Customer-Oriented Sales Model is developed by authors and it is unique while it does not neglect any of important sales activities. The model represents the sales flow from the customer where needs are created, through the sales process, where supplier recognize the needs and prepare products or services to satisfy identified needs, till post sales activities, where supplier has a chance to delight the customer and transfer added value. Product-team organizational structure, supported by detail plan of manufacturing process, high quality performance indicators, with additional sustain in IT technology and intangible resources, offers the possibility of establishing a good basis for the sales process. The sales process will not start if the supplier did not recognize the needs and desires of potential customer. Although the marketing and sales departments are more involved in the sales process, the attendance of other departments in the company is undisputed. All departments have a stipulation to cooperate with one other and be interoperable because this is the only way if company wants to procure an offer that will satisfy customer needs and fulfill required conditions. As already known sales process depends on a lot of macro and micro factors, company needs to deal with. County legislation and market factors are most important macro barriers. Firstly, they include all obstacles brought by the law, international conventions and agreements, trade restrictions, intergovernmental arrangements or government regulatory changes ${ }^{1}$ (Andersen, 2007; Carette, 2008). Market factors do not include only favorable economic condition, low interest rates or tax advantages. Factors like location, competition, timing or price level significantly affect whole sales process. On the other hand, there are tacit and explicit knowledge (Markus, 2001; Ammann, 2010; Gasik, 2011) that company can use, firstly for differentiation, but for maintainable development too. Special attention should be paid to tacit knowledge that is extremely difficult to obtain, impossible to copy and also difficult and expensive to be transferred and therefore can be source of long-term competitive advantage (Rahimić, 2006:143).

All activities of sales, all the time, must be interlaced with promotional activities in order to meet customers with products and services companies are selling. Before companies make 
PROBLEMS

OF MANAGEMENT

IN THE $21^{\text {st }}$ CENTURY

Volume 3, 2012

contact with the customer, they need to know who customer's decision maker is. Most often that is purchasing department or the company's management. Therefore, sales representatives need to pay more attention to these two departments. Other operating departments of the customer are also important because companies want to sell a product that will satisfy customer's needs and desires in multiple segments. A lot of companies forget about post sales activities. This is one of the main reasons for the high level of customer attrition rate. Product or service implementation, customer service and support, gathering customer feedback, continued customer relationship building, future sales forecasting, or sales evaluation are very important post sales activities that customers make it clear that the goal of cooperation is not only selling, but helping each other.

\section{Application of COS Model in Companies in Bosnia and Herzegovina}

Company's sales team needs to necessarily focus on creating value for customers firstly increasing their revenue, not just reducing costs. Increasing revenue is the long-term oriented strategy of the company, with opportunities to be feasible for many years. The cost leadership strategy can be fatal for the company, if they do not recognize the level at which they begin a threat to their growth capacity and innovation. COS Model helps companies to increase their income, but does not role out the possibility that investment in new system will cause an increase of costs.

\section{Research methodology}

The focus of the paper, like research aim, we talk about the awareness and acceptance of customer satisfaction issue as a key element by which companies can differentiate from their competition. The main working hypothesis is: International companies, as opposed to domestic, attach greater importance for building sales network focused on the customer. As a form of research we use data collection questionnaire. The technique was survey and way of realization was individual interviews. Research was implemented in the period January-May 2010 on the territory of Bosnia and Herzegovina. The sample size was 44 companies (20 international and 24 domestic companies). The sampling process required the following adjustments:

- International companies include companies with local offices, branches or subsidiaries on the territory of Bosnia and Herzegovina, or domestic companies where the control block of shares has some international company.

- Domestic companies include companies where the most of start-up capital is from Bosnia and Herzegovina.

- Companies need to deal in B2B sector, selling goods and services through their sales representatives.

- The research can be conducted only with the high management of companies.

The companies used for research were selected by simple random sampling from online database of companies ${ }^{2}$. Questionnaires were distributed to companies in several ways, mostly through e-mail or direct contact with company management. Companies that we used as research sample have a various ownerships, work in different business sectors (industries), sell a wide variety of products and services, they are geographically dispersed and different by size.

During the processing and presentation of results obtained by research, we used few 
methods, commonly non-parametric statistics, considering that research sample was relatively small. In some cases when we were not able to use any statistical test we presented our results through simple percentages or proportions. In case where this was possible ${ }^{3}$ with the proportion we used Chi Square test to determine whether certain groups (in this research, categories of domestic and international companies) are significantly different from anticipated

results or frequencies. $\chi^{2}=\sum_{i} \sum_{j} \frac{\left(\mathrm{o}_{i j}-\mathrm{E}_{\mathrm{ij}}\right)^{2}}{\mathrm{E}_{\mathrm{ij}}} \chi^{2}=\sum_{\mathrm{i}} \sum_{\mathrm{j}} \frac{\left(\mathrm{O}_{\mathrm{ij}}-\mathrm{E}_{\mathrm{ij}}\right)^{2}}{\mathrm{E}_{\mathrm{ij}}}$ Where: $\mathrm{O}$ - Observed frequencies, $\mathrm{E}-$ Expected frequencies. ${ }_{\mathrm{i}}$ For questions whose ${ }^{\mathrm{E}_{\mathrm{ij}}}$ answers were scaled from 1 to 5 or 1 to 7, we followed two procedures: Kolmogorov-Smirnov normality test (K-S) and Mann-Whitney-Wilcoxon test (M-W). K-S test was needed to determine if two datasets differ significantly and had the advantage of making no assumption about the distribution of data.

$\operatorname{Dn}=\sup _{x}|G(x)-\widehat{G} n(x)| D n=\sup _{x}|G(x)-\widehat{G} n(x)|$ Where $n-$ number of (independent) observations; $\widehat{\mathrm{G}}(\mathrm{x}) \widehat{\mathrm{G}}(\mathrm{x})$ - empirical cumulative distribution function (cdf); $\mathrm{G}$ - completely specified continuous theoretical cdf. M-W test like, non-parametric statistical hypothesis test, we used for assessing whether two independent samples of observations have equally large values. $U=n_{1} n_{2}+\frac{n_{2}\left(n_{2}+1\right)}{2}-\sum_{i=n_{1}+1}^{n_{2}} R_{i} U=n_{1} n_{2}+\frac{n_{2}\left(n_{2}+1\right)}{2}-\sum_{i=n_{1}+1}^{n_{2}} R_{i}$ Where: $\mathrm{U}-\mathrm{M}-\mathrm{W} \mathrm{U}$ test; $\mathrm{n}_{1} \mathrm{n}_{1}$ - sample size one; $\mathrm{n}_{2} \mathrm{n}_{2}$ - sample size two; $\mathrm{R}_{\mathrm{i}} \mathrm{R}_{\mathrm{i}}$ - rank of the sample size. With $\mathrm{M}-\mathrm{W}$ test we treated differences between the mean ranks, which indicated statistically significant or insignificant differences between observed categories. K-S test results are further checked by Shapiro-Wilk (S-W) test. $\mathrm{W}=\frac{\left(\sum_{\mathrm{i}=1}^{\mathrm{n}} \mathrm{a}_{1} \mathrm{x}_{(\mathrm{i})}\right)^{2}}{\sum_{\mathrm{i}=1}^{\mathrm{n}}\left(\mathrm{x}_{\mathrm{i}}-\overline{\mathrm{x}}\right)^{2}} \mathrm{~W}=\frac{\left(\sum_{\mathrm{i}=1}^{\mathrm{n}} \mathrm{a}_{1} \mathrm{x}_{(\mathrm{i})}\right)^{2}}{\sum_{\mathrm{i}=1}^{\mathrm{n}}\left(\mathrm{x}_{\mathrm{i}}-\overline{\mathrm{x}}\right)^{2}}$ Where: $\mathrm{X}_{\mathrm{i}} \mathrm{X}_{\mathrm{i}}-i$ th smallest number in the sample; $\overline{\mathrm{X}}=\frac{\left(\mathrm{x}_{1}+\cdots+x_{\mathrm{n}}\right)}{\mathrm{n}} \overline{\mathrm{X}}=\frac{\left(\mathrm{x}_{1}+\cdots+\mathrm{x}_{\mathrm{n}}\right)}{\mathrm{n}}$ - sample mean. The constants $\mathrm{a}_{\mathrm{i}} \mathrm{a}_{\mathrm{i}}$ are given by: $\left(a_{1}, \ldots a_{n}\right)=\frac{\mathrm{m}^{\mathrm{T}} \mathrm{v}^{-1}}{\left(\mathrm{~m}^{\mathrm{T}} \mathrm{v}^{-1} \mathrm{v}^{-1} \mathrm{~m}\right)^{1 / 2}}\left(a_{1}, \ldots a_{n}\right)=\frac{\mathrm{m}^{\mathrm{T}} \mathrm{v}^{-1}}{\left(\mathrm{~m}^{\mathrm{T}} \mathrm{v}^{-1} \mathrm{v}^{-1} \mathrm{~m}\right)^{1 / 2}}$ Where: $\mathrm{m}=\left(\mathrm{m}_{1}, \ldots, \mathrm{m}_{\mathrm{n}}\right)^{\mathrm{T}} \mathrm{m}=\left(\mathrm{m}_{1}, \ldots, \mathrm{m}_{\mathrm{n}}\right)^{\mathrm{T}}$ and $\left(\mathrm{m}_{1}, \ldots, \mathrm{m}_{\mathrm{n}}\right)\left(\mathrm{m}_{1}, \ldots, \mathrm{m}_{\mathrm{n}}\right)$ are the expected values of the order statistics of independent and identically-distributed random variables sampled from the standard normal distribution, and $\mathrm{V}$ is the covariance matrix of those order statistics (Royston, 1983; Villasenor and Estrada, 2009; Tasdan and Sievers, 2009; Drezner, Turel and Zerom, 2010). In some results presentations we excluded tables or diagrams, but they are presented in text form: $\{M-W=X ; p=X<>0.05$; Mean-rank 'INT/DOM' $=X / X$, Median (Md) 'INT/DOM' $=X / X\}$. In other cases, when it was apposite, we used cross-tabulation to show answers dynamism for certain categories on two juxtaposed and adjacent questions.

\section{Results of Research}

In hypothesis verification process we tried to get answers for several questions that helped us to identify representation level of CRM tools that companies use to deliver higher value for their industrial customers, and can be used as a good starting point for building long-term competitive advantage. It is known that all processes of differentiation are based on efficient balance between many internal and external variables. With presented research results we give answer for the question: "Do you think that customer satisfaction is companies business most important $\mathrm{KPI}^{4}$ ?"

With first question we tried to get an answer to the question what is the company's most important indicator for business success. The results we can present in diagram: 


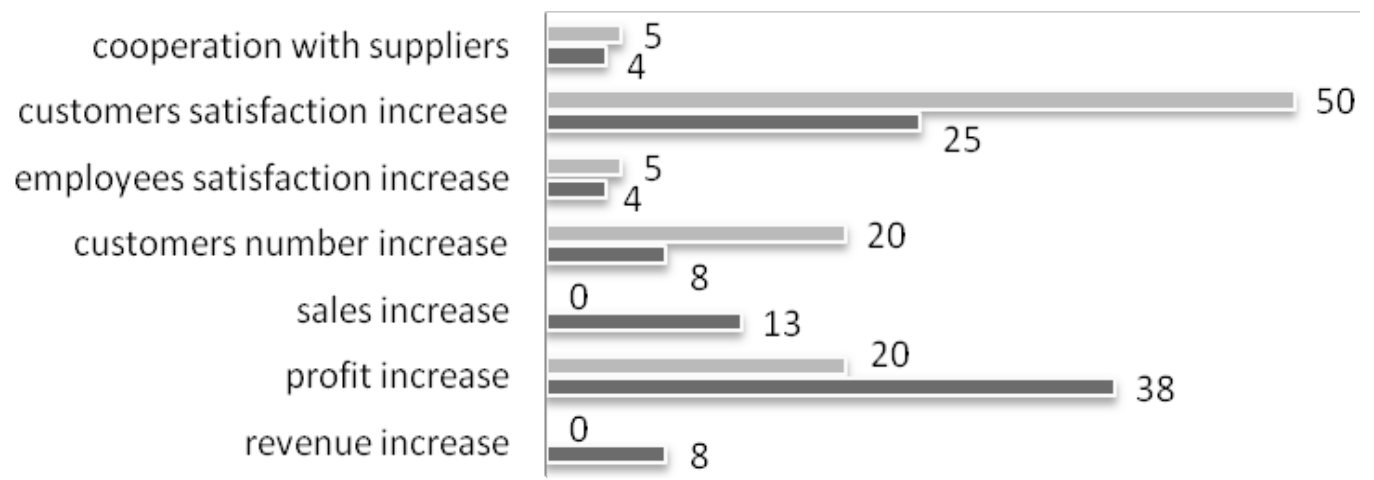

Figure 2: What is company's most important indicator for business success?

In the Figure 2 we can see that the most important indicator for international companies is customer satisfaction increase, and after that on the second place are profit increase and customer number increase. These results are reflection of modern marketing and business-oriented sales approaches, where companies' need to realize that the customer satisfaction increase is a basic tool for long-term operations and planning. On the other hand, domestic companies consider that the most important indicator for business success is profit increase. Although for very long time in business, the companies evaluated their business success on profit increase ratio, we can say that this policy is obsolete in international framework, and that international companies, as we can see in research results, consider some other indicators more important.

International companies have recognized the need of building sales network aimed at customer, and it can be said that they recognize the role of this indicator in their long-term oriented business. We can see also the noticeable trend for domestic companies to accept customer satisfaction increase as most relevant business indicator. It is interesting that none of international companies have not identified profit increase or sales increase as a key indicator of business success, while for domestic companies the lowest percentage of $4 \%$ are for indicators: employees satisfaction increase and successful cooperation with suppliers (Squire, Cousins and Brown, 2009; Kim, at al., 2010).

Next question was used to examine the level of two essential parameters. These parameters are the number of customers and customer's purchasing power. Companies were obligated to provide answers on Likert scale from 1 (it is not important at all) to 5 (very important). The results show that we do not have statistically significant difference between the perception of these parameters for domestic and international companies. For the first parameter, number of customers, we obtained the following results: $(\mathrm{M}-\mathrm{W}=192.000, \mathrm{p}>0.05$; Mean-rank 'INT' $=20.10$; Mean-rank 'DOM' $=24.50)$. For second parameter results are: $(\mathrm{M}-\mathrm{W}=207.000$, $\mathrm{p}>0.05$; Mean-rank 'INT' $=24.15$; Mean-rank 'DOM' $=21.13$ ). The median value for the both parameters and both group of companies is $(\mathrm{Md}=4)$. Although the results of testing those data do not show statistically significant difference between the two groups of companies, it was expected that most of them respond that the both parameters are very important for them.

Further, companies were obligated to evaluate their knowledge level about the current financial situation of their customers. The Figure 3 shows that $75 \%$ of international companies and $67 \%$ of domestic are mostly or fully aware of the financial situation of their customers. Although the differences between international and domestic companies in this analysis are not significant, it can be said that international companies are more acquaint with those information, as opposed of domestic companies. An interesting fact, in deeper cluster analysis, is that $50 \%$ 
of companies that had sales increase in last five years, and $60 \%$ of the companies that had sales level unchanged, responded that they are generally familiar with the financial situation of their customer. On the other hand companies that had sales decrease in last five years responded that they are not inform in detail about financial condition of their customers.

घ International companies (\%) $\square$ Domestic companies (\%)

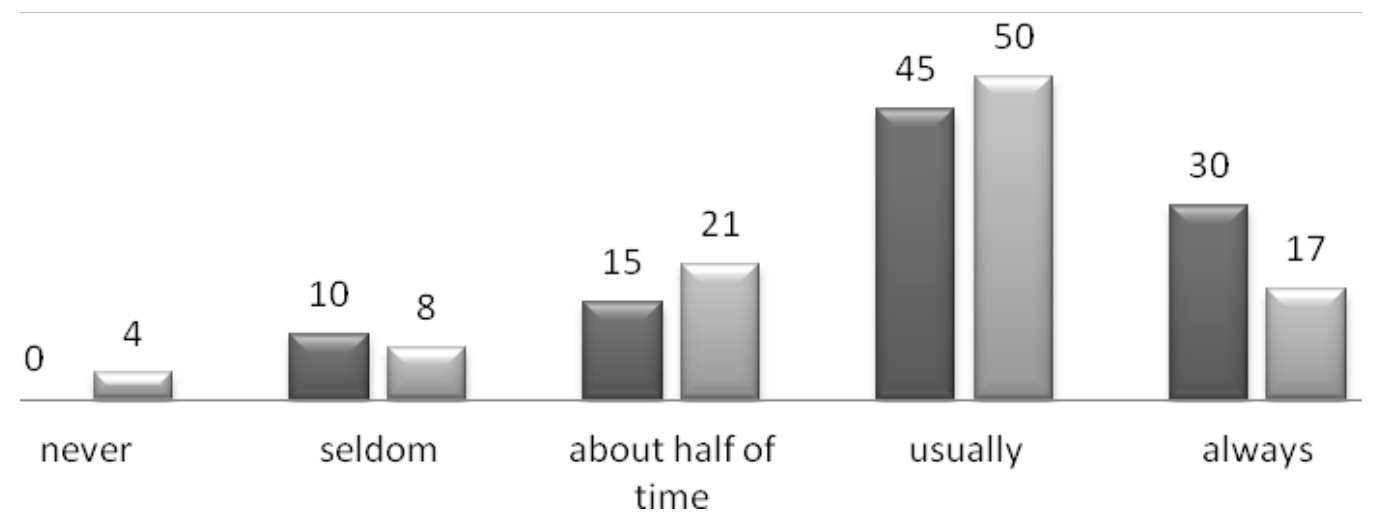

Figure 3: Are companies familiar with the financial situation of their customers?

In hypotheses checking process it was very important to analysis the frequencies of visiting customers companies by sales representatives. The results on Figure 4 show that $90 \%$ of sales representatives in international companies and only $54.18 \%$ in domestic are practicing visits to their customers at least once a month. The most interesting fact of this analysis is that $45.84 \%$ of domestic companies' sales representatives never, or once in three months are visiting their customers, while this is the case only for $10 \%$ of international companies. The largest percentages of companies that have achieved sales increase in last five years, most frequently visit their customers once in fifteen days. Two-thirds of the companies that had sales decrease in last five years said that they are visiting their customers less than once every three months. These results confirm, once again, that international companies have recognized the importance of direct and frequent cooperation with their customers (Ramsauer, 2005; Ferrer, Pastor and Gacia-Villoria, 2009). 


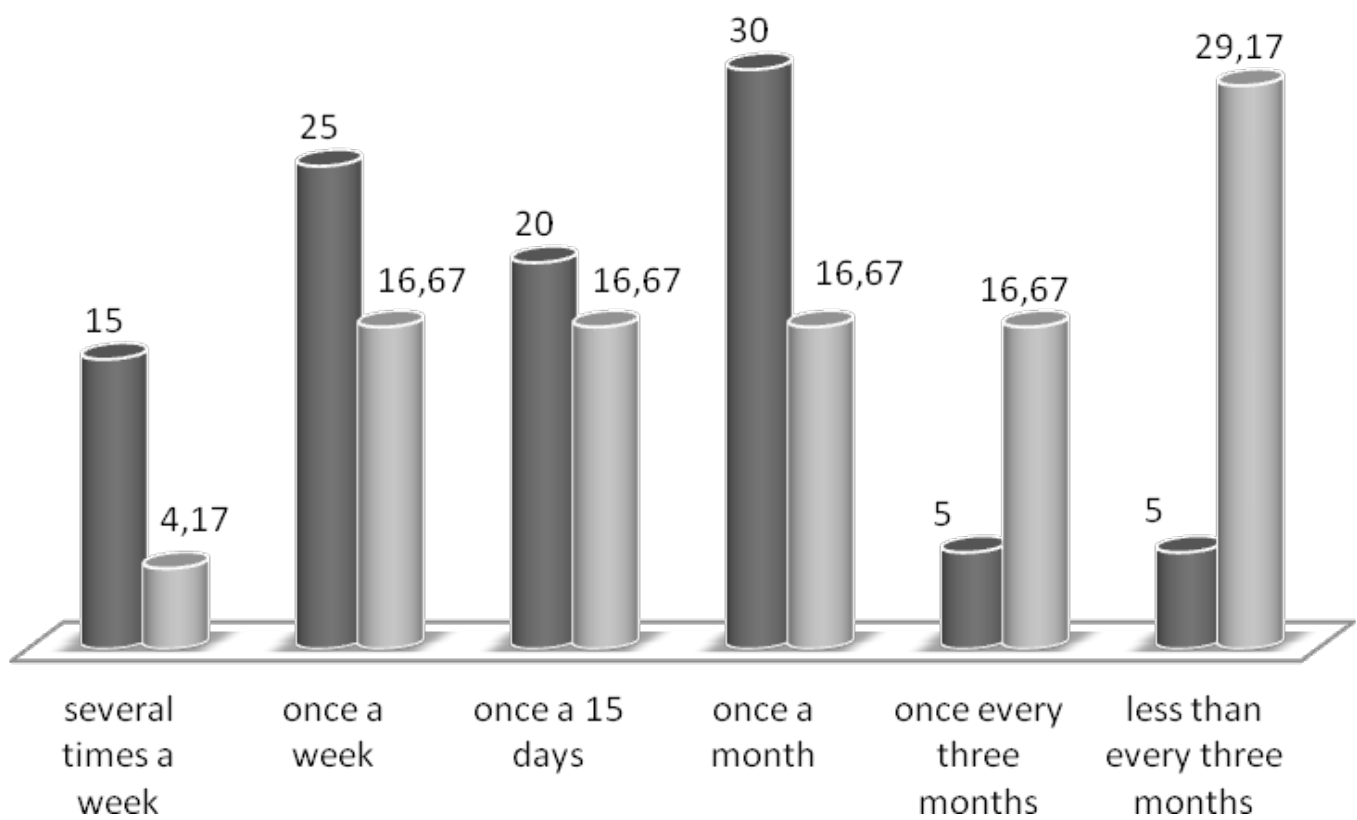

Figure 4: The intensity of customer visits by sales representatives.

With the next question we tried to get answers about six statements, which companies were obligated to evaluate on a scale from 1 (not at all agree) to 5 (strongly agree). Looking at the Table 1 we can observe that statistically significant difference appears in the statements: 2, 3 and 6. Taking into account the mean rank, we can notice that international companies often strive to show benefits that their customers will receive by using their products/services. Using theoretical background about sales processes, we can confirm that international companies recognized the importance of modern sales approaches. One of the sales theories implies process of helping customers, where the sales representatives use sales techniques to convince customers that he is only supplier that can solve that kind of problem. This is one of the most important characteristic of contemporary sales methods, and from research results we can conclude that international companies increasingly realized and accepted new sales methods, but that is not case with domestic companies. On the third statement, there is also a statistically significant difference, where we can see that international companies take a lot more care about quality of products and services they will offer to customers. Median values also show the differences.

All modern sales schools, especially those for training sales representatives with no experience, emphasize that if the customer refuses the offer, it usually means that some of the steps in sales process are not done properly. In short, this means that the potential customer never refuses sales representative for him personally, but only offer that he has. The results presented in statement six show that international companies better understand this element of the modern sales theory. Regarding the statements 1, 4 and 5 there was no statistically significant difference between two groups of companies. The most important thing is that both groups responded in accordance with the concepts of modern sales theories. Those results are confirmed also with median values. 
Table 2. Customers statements related to sales network establishment.

\begin{tabular}{|c|l|c|c|c|c|c|c|}
\hline $\mathbf{N}$ & \multicolumn{1}{|c|}{ STATEMENT } & MW test & $\mathbf{p}$ & $\begin{array}{c}\text { Mean } \\
\text { rank } \\
\text { 'DOM' }\end{array}$ & $\begin{array}{c}\text { Mean } \\
\text { rank } \\
\text { 'INT' }\end{array}$ & $\begin{array}{c}\text { Median } \\
\text { 'DOM' }\end{array}$ & Median 'INT' \\
\hline 1. & $\begin{array}{l}\text { Our products/services are created } \\
\text { exclusively by customer require- } \\
\text { ments }\end{array}$ & 187.500 & $p>0.05$ & 20.31 & 25.13 & 3.5 & 4.0 \\
\hline 2. & $\begin{array}{l}\text { We strive to show our customers the } \\
\text { benefits they will receive by using } \\
\text { our products / services }\end{array}$ & 173.500 & $p<0.05$ & 19.73 & 25.83 & 4.0 & 4.0 \\
\hline 3. & $\begin{array}{l}\text { We primarily offer quality products } \\
\text { /services to our customers }\end{array}$ & 174.500 & $p<0.05$ & 19.75 & 25.80 & 3.0 & 4.0 \\
\hline 4. & $\begin{array}{l}\text { We primarily offer products /services } \\
\text { our customers really need }\end{array}$ & 199.500 & $p>0.05$ & 20.81 & 24.53 & 3.5 & 4.0 \\
\hline 5. & $\begin{array}{l}\text { Complaints are inevitable in our daily } \\
\text { operations }\end{array}$ & 220.000 & $p>0.05$ & 23.33 & 21.50 & 3.0 & 3.0 \\
\hline 6. & $\begin{array}{l}\text { We believe that, if a customer } \\
\text { refuses our offer, he actually refused } \\
\text { our sales representatives. }\end{array}$ & 144.000 & $p<0.05$ & 26.50 & 17.70 & 3.0 & 2.0 \\
\hline
\end{tabular}

Figure 5 shows the research results for the question about what is the starting point when companies want to create their sales portfolio. We can say that results were expected and that $70 \%$ of international companies and only $42 \%$ of domestic, like focus for creating sales portfolio, use customer needs and expectations. These results show that international companies have realized that quality is not the most important product or servis characteristic, and that it cannot be a long-term support for a business. Identifying and satisfying customer needs and expectations, today for sure, is the most important business element for market oriented companies.

have the best quality products

$\square$ have the cheapest products

$\square$ have the products that customers really want

70

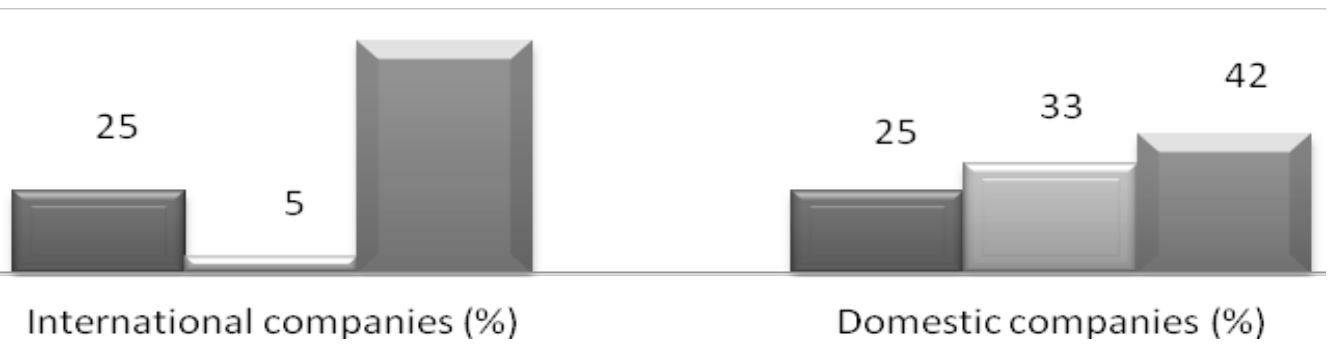

Figure 5: The most important starting point (focus) for creating companies sales portfolio. 
PROBLEMS

OF MANAGEMENT

IN THE $21^{\text {st }}$ CENTURY

Volume 3, 2012

After those results we analysis the possibility that companies use evaluation tools to identify their customer satisfaction level, and their plans for future evaluations. The results of these two issues are presented through cross-tabulation (Tables 3 and 4), divided by groups of companies. Disconcerting is that even $29 \%$ of domestic companies do not use evaluation tools for indentifying customer needs, while this percentage for international companies is only $15 \%$.

Table 3. Evaluation tools for international companies.

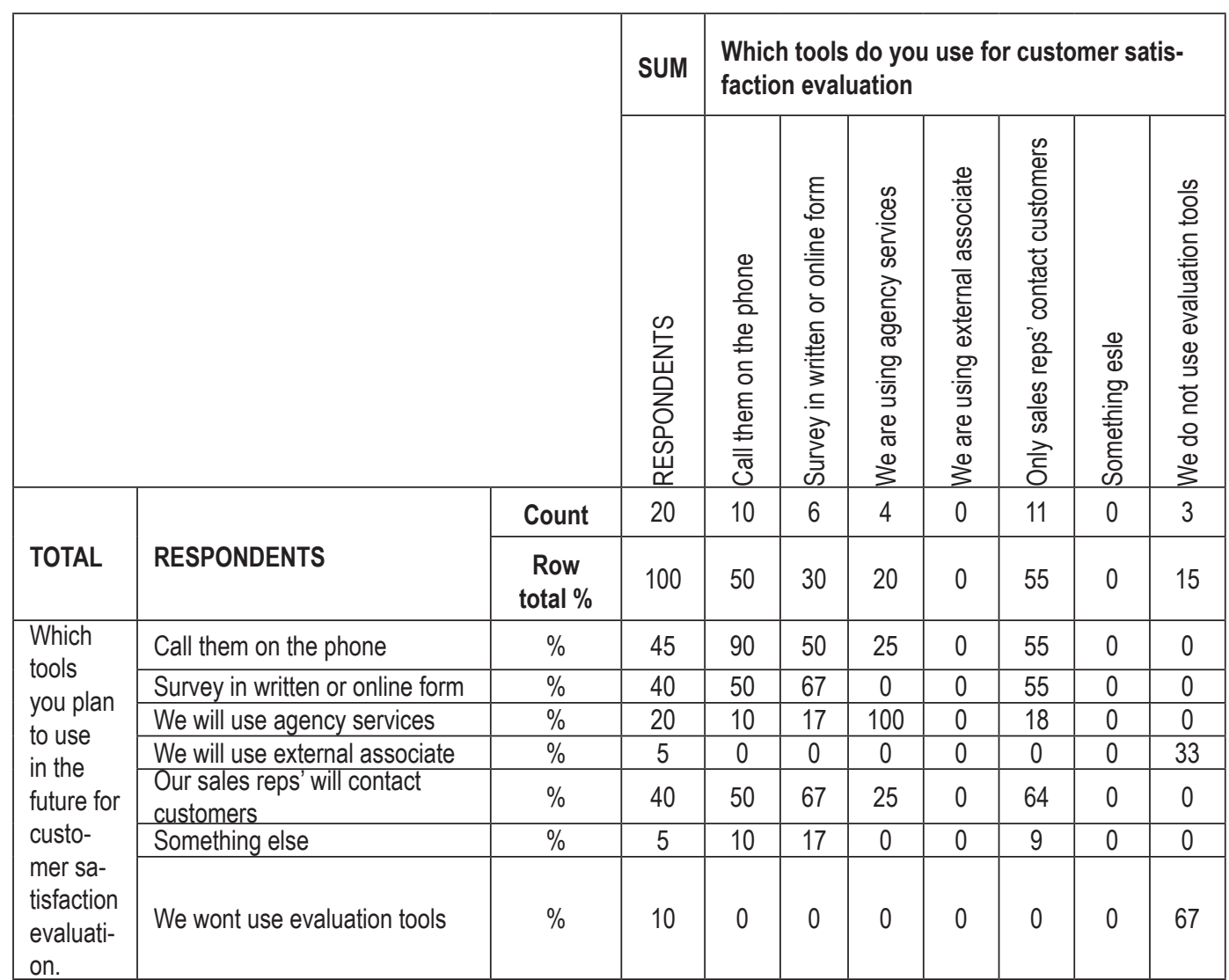

The management of international companies usually evaluates their customer needs through sales representatives in direct contact, and most of them will use this method in the future. On other hand, domestic companies mostly call their customers by phone, but in the future, except this method they will use surveys in written or online form.

Modern sales methods are recommending to companies to use sales representatives for the customer satisfaction evaluation because they know "market pulse" better that anyone, and can get the honest answers. For all evaluation tools external communication is very important, because the evaluation will be irrelevant if customers do not provide honest and fully answers 
Table 4. Evaluation tools for domestic companies.

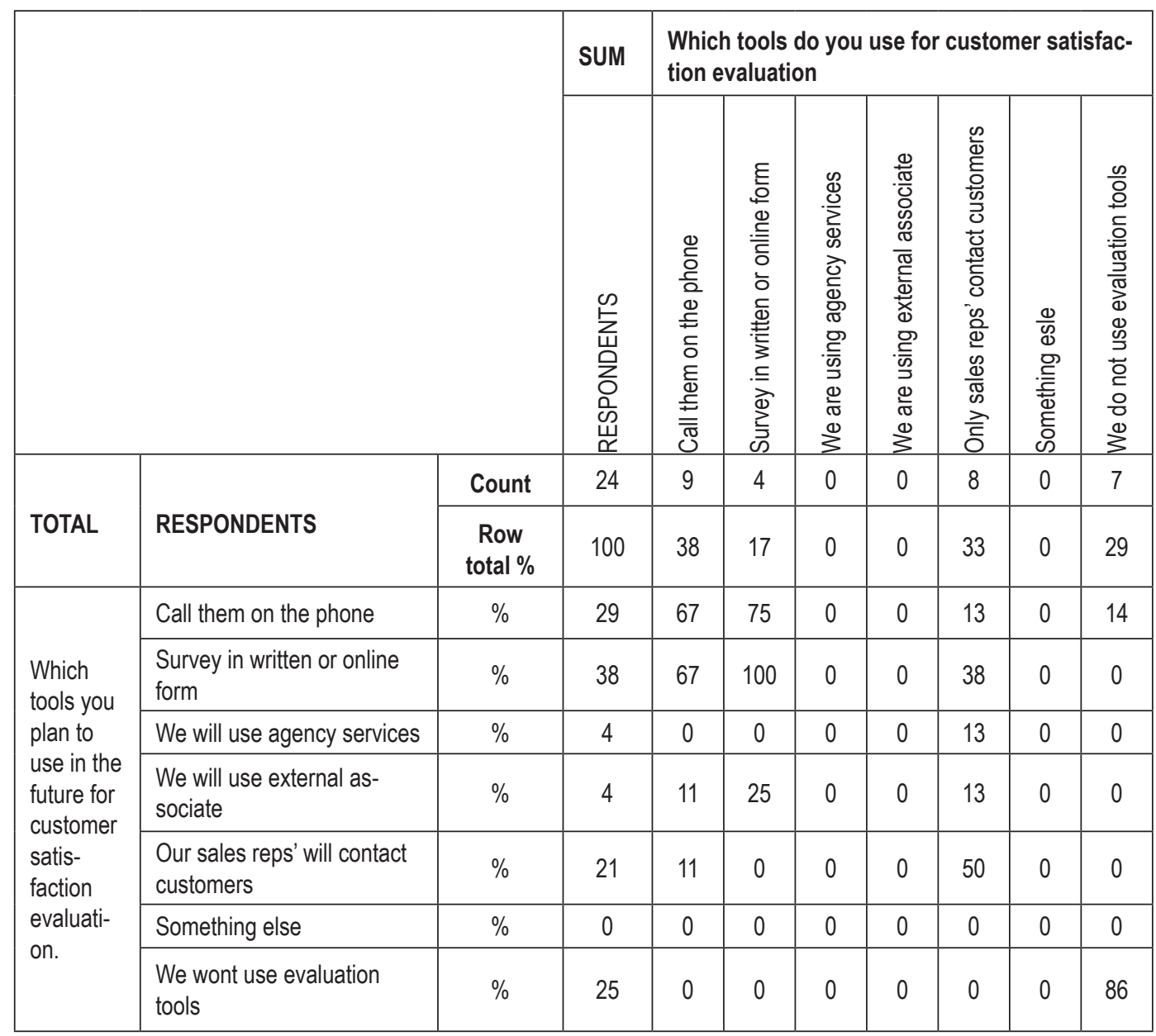

In the end of this research, it is clear that the hypothesis: International companies, as opposed to domestic, attach greater importance for building sales network focused on the customer, is finally confirmed.

\section{Conclusion}

Customer satisfaction measurement is science supported and system oriented method of collecting all necessary information that companies can use for future planning and business strategy adjustments. Without process of identifying customer requirements any business step can be needless, and future of the company totally uncertain. In the modern business environment, characterized by rapidly and uncertainty changes caused by the processes of globalization, internationalization and rapid technological and personnel progress, survival and long-term development of the company depends of company's ability for continual customer satisfaction for all anticipated needs and requirements.

In this research, we have presented the application of the Customer-Oriented Sales (COS) Model, which includes customer satisfaction like one inseparable variable in sales process. Companies that sell their products and services in B2B sector should especially support and recognize importance of customer satisfaction tools, like a possibility of creating a framework for building COS Model. 
PROBLEMS

OF MANAGEMENT

IN THE $21^{\text {st }}$ CENTURY

Volume 3, 2012

104

Using analysis between the two groups of companies in Bosnia and Herzegovina, we came to the conclusion that much more international companies consider that customer satisfaction is the most important element that can be used in the process of differentiation. On the other hand, domestic companies still believe that for today's consumer's some other elements are more important. Sales policy that always puts customer needs and requirements in the focus is the only way to ensure company loyalty of its customers, which represents the basis for establishing modern sales methods.

Based on the results of theoretical and empirical research can be concluded that customer satisfaction focused on finding opportunities to create value for the customer is good base for creating COS Model. Creating value for customers, firstly based on revenue increasing, not only reducing prices, companies can achieve satisfaction and loyalty of their customers at the same time, and finally achieve strategic plans. Regardless of the strong competition in B2B sales, using the COS Model and customer satisfaction tools, companies can differentiate themselves from competition and become market leader.

\section{References}

Ammann, E. (2010). Intellectual Capital Development by Means of Knowledge Conversions. In: Proceedings of the European Conference on Intellectual Capital, 29-30 March, Lisbon, Portugal: Academic Publishing Limited, pp. 44-53.

Andersen, C. B. (2007). The Duty to Examine Goods under the Uniform International Sales Low - An Analysis of Article 38 CISG. European Business Low Review, 18 (4), 797-814.

Arnett, D., Badrinarayanan, V. (2005). Enhancing customer-needs-driven CRM strategies: Core selling teams, knowledge management competence, and relationship marketing competence. Journal of Personal Selling \& Sales Management, 25 (4), 329-343.

Bansai, P. (2001). CRM comes to B2B. Banker, 151 (905), 98.

Brdarević, S. (2002). Customer Satisfaction Measurement Methods According to ISO 9001:2000. Faculty of Mechanical Engineering Zenica, Mechanical Engineering, 4 (6), 252.

Carette, N. (2008). Direct Contractual Claim of the Sub-buyer and International Sale of Goods: Applicable Law and Applicability of the CISG. European Review of Private Law, 16 (4), 583-605.

Charan R. (2007). What the customer wants you to know. Penguin Group, London.

Dowling, G. (2002). Customer Relationship Management: In B2C Markets, Often Less is More. California Management Review, 44 (3), 87-104.

Ferrer, L., Pastor, R., \& Garcia-Villoria, A. (2009). Designing salespeople's routes with multiple visits of customers: A case study. International Journal of Production Economics, 119 (1), 46-54.

Gasik, S. (2011). A model of project knowledge management. Project Management Journal, 42 (3), 23 44.

Gitomer, J. (2008). The Sales Bible. Nukleus, Beograd.

Godin, S. (2010). To Win, Create What's Scarce. Harvard Business Review, 88 (11), 46.

Gotzamani, K. (2010). Results of an empirical investigation on the anticipated improvement areas of the ISO 9001:2000 standard. Total Quality Management \& Business Excellence, 21 (6), 687-704.

Hopkins, T. (2005). How to Master the Art of Selling. Finesa, Beograd

Kim, K. K., Park, S. H., Ryoo, S.Y., \& Park S. K. (2010). Inter-organizational cooperation in buyersupplier relationships: Both perspectives. Journal of Business Research, 63 (8), 863-869.

Kleinaltenkamp, M., et al. (2011). Die Kunden der Kunden im Visier. Harvard Business Manager, February 2011, 43-47.

Kovačić, G. N. (2011). Otvaranje "crne kutije” potrošačevog mozga. Retrieved from: http://www.vjesnik. $\mathrm{hr} /$ Article.aspx?ID=9F62F196-8FA4-4FF6-A98F-EA9EC1BA15DB 
Zijada RAHIMIĆ, Kenan UŠTOVIĆ. Customer Satisfaction as a Key Factor in Building and Maintaining Competitive Advantages of Companies

Labus, M., Stone, M. (2010). The CRM behaviour theory - Manage corporate customer relationships in servis industries. Journal of Database Marketing \& Customer Strategy Management, 17 (3/4), $155-173$

Markus, M. L. (2001). Toward a Theory of Knowledge Reuse: Types of Knowledge Reuse Situations and Factors in Reuse Success. Journal of Management Information Systems, 18 (1), 57-93.

Oakland, S. J., Oakland, D. (1998). The links between people management, customer satisfaction and business result. Total Quality Management, 9 (4/5), 185-190.

Plank, R. E., Blackshear, T. (1997). Standardizing the sales process: Applying TQM to the industrial selling function. American Business Review, 15 (2), 52.

Porter, E. M., Kramer, R. M. (2011). The Big Idea: Creating Shared Value. Harvard Business Review, 89 $(1 / 2), 62-77$.

Rahimić, Z. (2006). Izgradnja konkurentskih prednosti preduzeća kroz njegova strateška opredjeljenja. Sarajevo: Ekonomski fakultet u Sarajevu.

Ramsauer, D. (2005). Visit your customers. Design News, 60 (6), 20.

Richard, J. E., Thirkell, P. C., \& Huff, S. L. (2007). An Examination of Customer Relationship Management (CRM) Technology Adoption and its Impact on Business-to-Business Customer Relationships. Total Quality Management \& Business Excellence, 18 (8), 927-945.

Roger, M. (2010). The Age of Customer Capitalism. Harvard Business Review, 88 (1/2), 58-65.

Rogers, B., Stone, M., \& Foss, B. (2008). Integrating the value of salespeople and systems: Adapting the benefits dependency network. Journal of Database Marketing \& Customer Strategy Management, 15 (4), 221-232.

Ryals, L., Davies, I. (2010). Vision Statement: Do You Really Know Who Your Best Salespeople Are? Harvard Business Review, 88 (12), 34-35.

Šehić, Dž. (2002). Strateški menadžment. Slovo Mostar, Sarajevo

Squire, B., Cousins, P. D., \& Brown, S. (2009). Cooperation and Knowledge Transfer within Buyer-Supplier Relationships: The Moderating Properties of Trust, Relationship Duration and Supplier Performance. British Journal of Management, 20 (4), 461-477.

\section{(Endnotes)}

1 One of the international conventions is: The United Nations Convention on Contracts for the International Sale of Goods (abbrev. CISG).

2 As the primary online database of companies has been used: www.poslovni-adresar.ba

3 If any of the expected cell frequencies of Chi Square test are less then five.

4 KPI (Key Performance Indicator)

Advised by Dževad Šehič, School of Economics and Business, Sarajevo, Bosnia and Herzegovina

Received: December 21, 2011

Accepted: March 21, 2012

\begin{tabular}{ll} 
Zijada Rahimić & Associate Professor, The School of Economics and Business Saraje \\
& Trg Oslobođenja - Alija Izetbegović 1, Sarajevo, Bosnia and Herzegovi \\
& Phone: + 38733 275-998; Fax: + 38733 275-994. \\
& E-mail: zijada.rahimic@efsa.unsa.ba \\
\hline Kenan Uštović & General Director, NCH Bosnia d.o.o. Sarajevo, Kaptol 32, Sarajevo \\
& Bosnia and Herzegovina. \\
& Phone: + 387 61 349-679. \\
& E-mail: kenan.ustovic@nch.com
\end{tabular}

